\title{
Film as part of the thesis and mounting as a method for the social sciences
}

\author{
Keywords \\ Decolonized methodologies, Film, History of Space, Montage, Thesis.
}

My argument is that the history of space can be built by montage. I'm a documentary filmmaker and editor. I understand film as a support for writing in fragments. I think that the filmic form, capable of carrying movements and times, testimonies and texts, past and present, is a suitable support for the history of space. There is a visual form of knowledge and a wisdom of the gaze, as in Warburg's Atlas, largely disregarded by the academy as a way of producing knowledge. If montage is a polyphonic device that uses forgotten remains and heterogeneous narrations to dismantle the official story and reassemble another story from its critical constellations, no instrument seems to me more adequate than a film to execute it. Through the search for other ways of narrating the urban experience, following Benjamin from the rags and the residues, operating knowledge from the anarchic potentialities of the fragment and the problematization through doubt, through the incomplete and through the unfinished. For Didi-Huberman, the empirical and creative exercise proposed by Benjamin is capable of bringing out other possibilities from the dismantling of certainties. It allows us to think through the differences in the gaps left between the fragments. The montage allows for the simultaneity of times and the emergence of symptoms, the revelation of failures, conflicts, heterogeneity, in perforating tradition and colliding with the text. If montage serves all this, it also serves the decolonization of perspectives and methodologies, serves to narrate the history of subalterns and the hidden histories of empires. It also can be used to articulate memory, narration and history in the attempt to grasp reality. I propose the use of cinematographic montage as a method of knowledge production, as an important part of the research and whose result will be a constitutive and inseparable part of the thesis. Film as a method for the social sciences. In addition to assembling the fragments, the author's narrative interference is a critical point of the proposed experience. Delivering an account of the position from which one narrates is, therefore, fundamental. The narration does not impose itself as a voice of God over the material, as it neither affirms nor has certainties. It is organized on the incompleteness of the process. The narration sheds light on the background of the painting, on what History disregarded, on what was considered disposable or unimportant by the discourse of the dominator. It is thinking through differences and from the cracks of what was enunciated by the authority. It is thinking from accidents and ghosts. I propose the integration of the result of film montage experience in the general organization of the thesis, so that the chapters can vary between the two supports, text and film, being organized according to what the material itself indicates. 